\title{
Paleomagnetic Evidence for Post-Devonian Displacement of the Avalon Platform (Newfoundland)
}

\author{
Dennis V. Kent \\ Lamont-Doherty Geological Observatory of Columbia University, Palisades, New York 10964
}

\begin{abstract}
The possibility that the Avalon Platform, where the Avalonian lithotectonic belt is best developed, was involved in late Paleozoic displacement was tested by paleomagnetic study of red sandstones of the Upper Devonian Terrenceville Formation of eastern Newfoundland. Two magnetization directions were identified by thermal demagnetization analysis of 60 oriented samples from 10 sites: a high blocking temperature, thermally discrete $A$ component of normal and reversed polarity, and an intermediate blocking temperature, thermally distributed $B$ component of reversed polarity. The B component ( $D=185.9^{\circ}, I=-3.3^{\circ}, a_{95}=7.2^{\circ}$ for $N=8$ sites) is interpreted as a postfolding secondary magnetization and gives a paleomagnetic pole position (latitude $=43.6^{\circ} \mathrm{N}$, longitude $=117.1^{\circ} \mathrm{E}$ ) near Early to Late Permian paleopoles for North America. The A component $\left(D=181.6^{\circ}, I=28.0^{\circ}, a_{95}=\right.$ $10.1^{\circ}$ for $N=9$ sites) is interpreted as the characteristic magnetization possibly dating from near the time of deposition of the Terrenceville Formation. The corresponding paleomagnetic pole position (latitude $=27.4^{\circ} \mathrm{N}$, longitude $=123.5^{\circ} \mathrm{E}$ ) falls within a group of Late Devonian-early Carboniferous paleopoles obtained from the Acadia displaced terrain, encompassing the coastal areas of New England and the Canadian maritimes which form another part of the Avalonian belt. These paleopoles are systematically offset by $15^{\circ}$ to $20^{\circ}$ in latitude from coeval pole positions obtained from cratonic North America. Thus the Avalonian belt of the northern Appalachians, which is thought to represent a remnant of a Precambrian and early Paleozoic microcontinent on tectonostratigraphic considerations, appears to correspond to a late Paleozoic displaced terrain on the basis of paleomagnetic evidence.
\end{abstract}

\section{INTRODUCTION}

The Avalonian belt is a terrain of upper Precambrian rocks, locally overlain by a small thickness of Paleozoic strata characterized by fossils of the Atlantic realm, which can be traced along the southeastern margin of the Appalachians (Figure 1) [Williams, 1978, 1979]. The lithotectonic development and its contrast with adjacent areas suggest that the Avalonian belt, particularly in the northern Appalachians, is a remnant of a late Precambrian and early Paleozoic microcontinent [Schenk, 1978].

Interpretation of late Paleozoic paleomagnetic data from North America suggests that part of the Avalonian belt, encompassing eastern Massachusetts and the coastal volcanic belt of Maine and New Brunswick, also had an active later history and did not reach its present position with respect to cratonic North America until the late Carboniferous. This area, referred to as the Acadia displaced terrain on the basis of paleomagnetic evidence, was apparently situated some $15^{\circ}$ of latitude $(\sim 1500 \mathrm{~km})$ farther south in the early Carboniferous [Kent and Opdyke, 1979], Middle to Late Devonian [Kent and Opdyke, 1978; Van der Voo et al., 1979; Irving, 1979] and perhaps in the Siluro-Devonian [Kent and Opdyke, 1980].

The question arises as to whether the entire Avalonian belt, distinguished primarily by its late Precambrian-early Paleozoic geology, is a continuous terrain and shared the same late Paleozoic displacement history documented for one of its parts, Acadia. Of particular interest is the relationship of the northern extremity of the Avalonian belt on the Avalon Platform of Newfoundland to the Acadia portion to the south. The position of Newfoundland plays a central role

Copyright 1982 by the American Geophysical Union.

Paper number 2B1146.

0148-0227/82/002B-1146\$05.00 in paleogeographic reconstructions of the Atlantic-bordering continents because it provides the most direct link in conventional reconstructions to related geological zones in western Europe. Although a nearby position of the Avalon Platform and Acadia is suspected on the basis of their similar early lithotectonic features, a common displacement history in the later Paleozoic nevertheless requires confirmation due to lack of continuous exposure across the Gulf of St. Lawrence. In this regard, preliminary paleomagnetic data from the Piedmont of the southern Appalachians, parts of which are thought to represent another part of the Avalonian belt, offer no convincing evidence for large latitudinal displacements in the late Paleozoic [Ellwood, 1982].

To test the hypothesis that the Avalon Platform shared a common movement history with Acadia, a paleomagnetic study of Devonian or lower Carboniferous stratified rocks from Newfoundland is required. An adequate number of reliable paleopole determinations from rock units of these ages are available for comparison from both cratonic North America and Acadia. Paleopole data from rocks of these ages most clearly demonstrate the displaced nature of Acadia with respect to cratonic North America. Stratified units are desirable for documentation of the paleohorizontal. With this purpose in mind, the red sandstones and siltstones of the Upper Devonian Terrenceville Formation from eastern Newfoundland were sampled for paleomagnetic study.

\section{Geological Setting and Sampling}

The Terrenceville Formation is a narrow belt of clastic sedimentary rocks exposed along the south side of Fortune Bay on the Burin Peninsula, near to the town of Terrenceville (latitude $=47.7^{\circ} \mathrm{N}$, longitude $=54.7^{\circ} \mathrm{W}$ ). These rocks are one of the few records of Devonian deposition on the Avalon platform of eastern Newfoundland [Williams, 1969]. According to Bradley [1962] the unit is at least $300 \mathrm{~m}$ thick 8709 


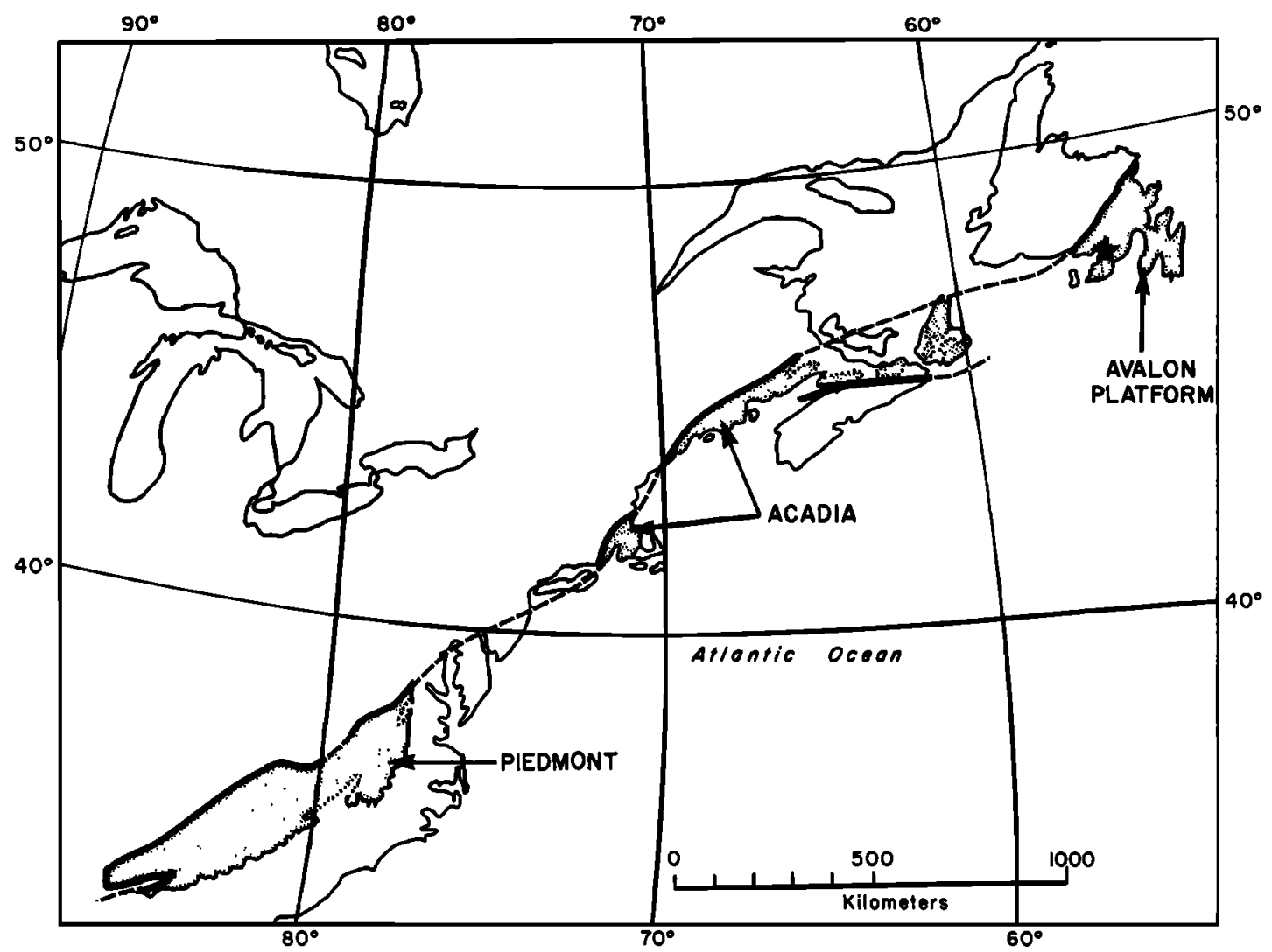

Fig. 1. Distribution of the Avalonian lithotectonic belt (shaded) in the Appalachians of North America [from King, 1977]. Star marks location of Terrenceville, Newfoundland.

sandstone, with minor amounts of gray-green shale and red mudstone, a lithological association consistent with other evidence for a fluviatile environment of deposition. Plant fossils are reported as fairly common and well preserved in the finer-grained units and are regarded as of Late Devonian age.

The Terrenceville Formation is the youngest stratified unit in the area and is unmetamorphosed. An erosional unconformity is inferred at the unexposed base of the formation from the presence of pebbles of older rock units within conglomerates of the Terrenceville Formation. The unit is overlain along a steep thrust fault contact by the Southern Hills Formation, which is thought to be of Precambrian age [Bradley, 1962].

A total of 60 oriented drill core samples were collected from 10 sites distributed along the sea cliff exposures west of Terrenceville. Bedding attitudes are somewhat variable from site to site but generally have westerly dips of less than $40^{\circ}$. Sampling was concentrated in the finer-grained red sandstone units, which generally appeared fresh although not very well indurated.

\section{Magnetic Measurements}

The natural remanent magnetization (NRM) of the samples was measured with either a $7-\mathrm{Hz}$ flux gate spinner magnetometer [Molyneux, 1971] or a cryogenic magnetometer [Goree and Fuller, 1976]. NRM intensities are typically in the range $10^{-3}$ to $10^{-2} \mathrm{~A} \mathrm{~m}^{-1}$.

To resolve the magnetization components contributing to the NRM, all samples were subjected to progressive thermal demagnetization. Between six and 12 temperature steps were used, up to a maximum of about $680^{\circ} \mathrm{C}$, when the magnetizations either dropped to within instrumental noise levels or became dominated by spurious components arising from exposure to stray fields during demagnetization and measurement. Several pilot samples were progressively demagnetized up to a peak alternating field (af) of $80 \mathrm{mT}$ prior to thermal treatment. A representative subset of specimens cut from the samples was saved for chemical demagnetization studies.

Vector end point diagrams illustrating demagnetization behavior are shown in Figure 2. Most samples show linear demagnetization trajectories, and these are the basis for calculation of one or more component directions for each sample by linear regression analysis. The significance of these trajectories can be understood by considering the presence of two main components of magnetization which are distinguished on the basis of blocking temperature spectra: one that is carried over a narrow range of high demagnetization temperatures, a thermally discrete (referred to as the A) component, and another which is carried over a broad range of intermediate temperatures, a thermally distributed (B) component.

The A component is observed in most (42) samples as a linear trajectory tending toward the origin during the final stages of demagnetization, usually between $660^{\circ}$ and $680^{\circ} \mathrm{C}$. This trajectory indicates either a downward dipping direction to the south (e.g., Figures $2 a-2 c$ ) or an upward dipping direction to the north (Figures $2 d$ and $2 e$ ). The presence of the A component is usually readily discerned on demagnetization diagrams because it constitutes a significant fraction of the total NRM. Nevertheless, the narrow temperature 


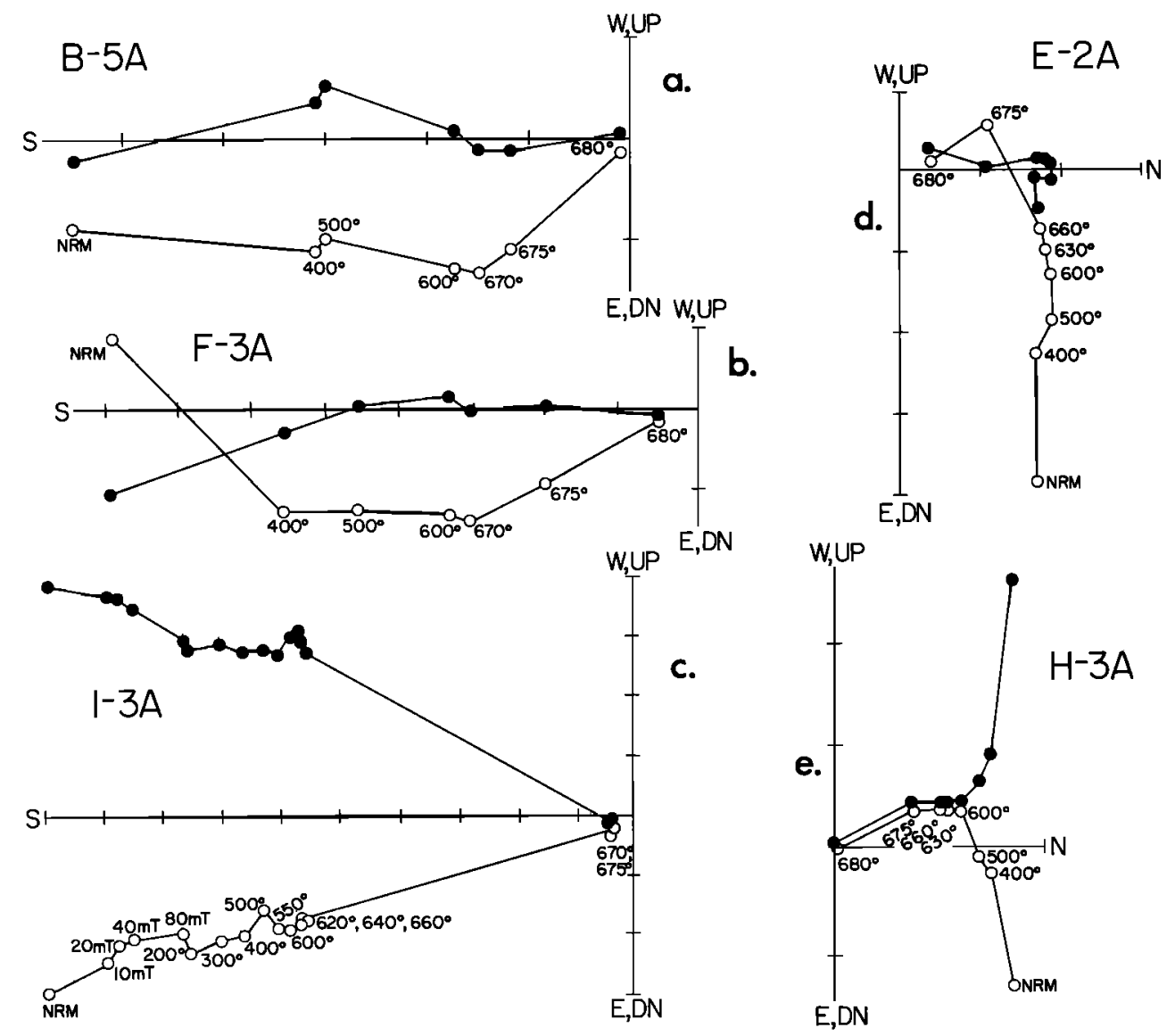

Fig. 2. Orthogonal projections of vector end points [Zijderveld, 1967] illustrating demagnetization behavior of samples from Terrenceville Formation. Open (solid) circles are projections on vertical (horizontal) planes at indicated levels of af or thermal demagnetization. Magnetization units on axes are in $10^{-3} \mathrm{~A} \mathrm{~m}^{-1}$.

range that it occupies often presented some experimental difficulty with regard to precise resolution. There may also be some encroachment of lower blocking temperature components into the narrow temperature band of the discrete component which tends to diminish the usable length of and the number of demagnetizations defining the trajectory attributed to the A component, a situation commonly encountered in samples with a northerly direction (e.g., Figures $2 d$ and $2 e$ ). In these latter cases, an estimate of the A component directions was obtained by anchoring the last one or two demagnetization steps to the origin.

The B component can be isolated in one half (30) of the samples as a linear trajectory (three or more colinear points) over an intermediate temperature range of demagnetization, typically between $400^{\circ} \mathrm{C}$ and as high as $670^{\circ} \mathrm{C}$. Although present over a temperature range that is 1 order of magnitude greater than for the A component (more than $250^{\circ} \mathrm{C}$ versus less than $20^{\circ}$ ), the $B$ component, where identified, usually contributes about an equal portion to the NRM. The B component trajectory typically has a shallow, southerly direction which does not go toward the origin and can therefore be distinguished from the southerly direction of the A component on the demagnetization diagrams (Figures $2 a$ and $2 b$ ). In a few samples, however, the A and B components have a colinear trajectory (e.g., Figure $2 c$ ), that is, they both have essentially the same direction. To maintain a consistent categorization of the components on the basis of blocking temperatures and to admit the possibility that the direction of the A and B components may sometimes coincide in individual samples, the discrete high-temperature trajectory (in this case, for example, above $660^{\circ} \mathrm{C}$ ) is assigned to the $\mathrm{A}$ component and the intermediate temperature trajectory $\left(300^{\circ}-660^{\circ} \mathrm{C}\right)$ to the $B$ component. Samples in which the $B$ component could not be resolved either gave incoherent demagnetization results and are judged magnetically unstable (an A component also is not isolated) or showed curvature in the demagnetization trajectory which indicates that more than a single component was being removed, as seemed to be the case in many samples with a northerly oriented A component (e.g., Figures $2 d$ and $2 e$ ).

The distribution of $\mathrm{A}$ component directions is shown in Figure 3 and Table 1. These sample directions fall into two populations. The mean direction for the northerly set $(D=$ $358.2^{\circ}, I=-28.8^{\circ}$ for 14 samples) is close to antiparallel to that of the southerly set $\left(D=183.7^{\circ}, I=24.9^{\circ}\right.$ for 28 samples). This geometry indicates that the A component magnetizations have been successfully isolated on the average from the $B$ component magnetizations. Inverting the northerly set of directions for calculation, an overall characteristic mean direction, after correction for bedding tilt, of $D$ $=181.6^{\circ}, I=28.0^{\circ}\left(k=27, a_{95}=10.1^{\circ}\right)$ for $N=9$ sites is obtained. Essentially the same grouping and orientation are apparent before tilt correction $\left(D=175.8^{\circ}, I=26.2^{\circ}, k=26\right.$, $a_{95}=10.3^{\circ}$ ).

The site mean directions of the $B$ component are shown in Figure 4 and Table 2. These give an overall mean of $D=$ 
THERMALLY DISCRETE COMPONENT

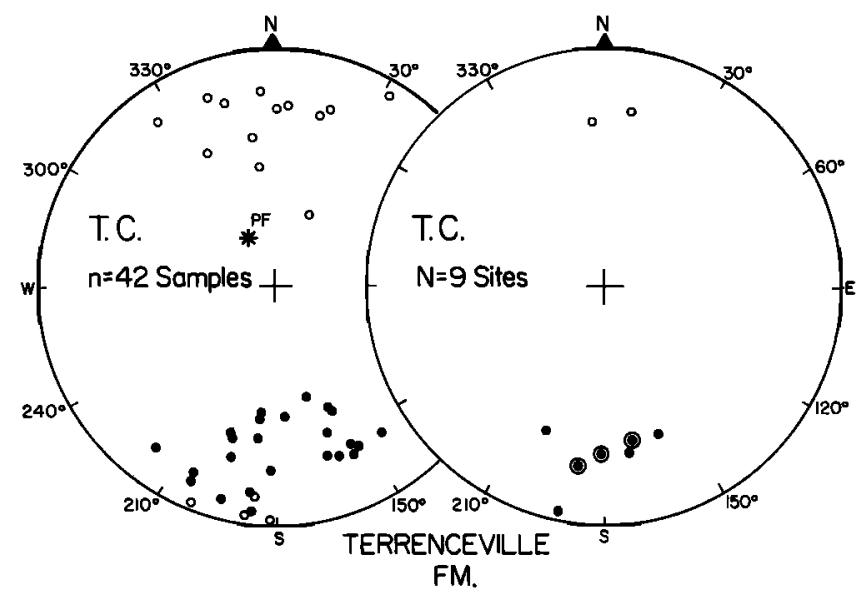

Fig. 3. Distribution of characteristic A component magnetization directions for samples (left) and by site means (right). Open (solid) circles plotted on upper (lower) hemisphere of equal-area projection. Encircled solid symbols on right diagram denote sites which contain both normal and reversed polarity samples; the normal polarity directions have been inverted to calculate the site mean. P. F. on left diagram is direction of present geomagnetic field at sampling locality.

$185.9^{\circ}, I=-3.3^{\circ}\left(k=61, a_{95}=7.2^{\circ}\right)$ for $N=8$ sites. The mean direction is again similar after tilt correction $(D=$ $\left.184.9^{\circ}, I=5.8^{\circ}\right)$, but the grouping is poorer $\left(k=35, a_{95}=\right.$ $9.6^{\circ}$. . Unfortunately, the difference in the estimate of the precision parameter $k$ before and after tilt correction is not significant at the $95 \%$ confidence level according to $f$ ratio tests [McElhinny, 1964] Nevertheless, the mean B component is distinguishable from the $A$ component mean at the 95\% confidence level, before or after tilt correction, since their respective cones of confidence do not intersect.

\section{INTERPRETATION OF RESULTS}

The mean B component gives a calculated paleopole position at $43.6^{\circ} \mathrm{N} 117.1^{\circ} \mathrm{E}\left(d p=3.6^{\circ}, d m=7.2^{\circ}\right)$ before correction for bedding tilt. The better grouping of these directions before tilt correction suggests that the B compo-
THERMALLY DISTRIBUTED COMPONENT

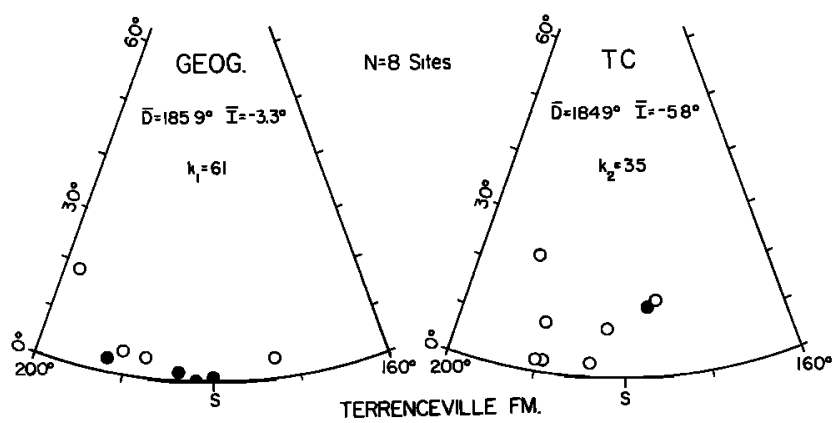

Fig. 4. Distribution of site-mean B component magnetization directions, plotted before (left diagram) and after (right diagram) bedding tilt correction. Open (solid) circles plotted on upper (lower) hemisphere of segments of equal-area projection. Mean directions $(D$, declination, and $I$, inclination) and precision parameter [Fisher, 1953], $k$ and $k_{2}$, before and after tilt correction, are shown for $N=8$ sites.

nent magnetization may be secondary, acquired after deposition and tilting of the Terrenceville Formation. The time of folding is not well constrained geologically but is in any case post-Late Devonian, the age of the Terrenceville Formation. The uniform polarity inferred for the B component is consistent with acquisiton during the Kiaman reversed interval in the Permo-Carboniferous [Irving and Pullaiah, 1976].

The A component gives a calculated paleopole position at $27.4^{\circ} \mathrm{N} 123.5^{\circ} \mathrm{E}\left(d p=6.1^{\circ}, d m=11.1^{\circ}\right.$ for $N=9$ sites $)$ after correction for bedding tilt. The fold test on the A component is inconclusive, since the site means yield virtually the same overall mean and grouping statistics before and after tilt correction. Therefore the possibility that the A component is also secondary and acquired after folding cannot be entirely discounted. The following observations, however, suggest that the A component predates the B component and may be nearly contemporaneous with deposition: (1) the very high stability of the A component, (2) linear decay to the origin indicating that the A component is the last remaining magnetization, (3) the presence of normal and reversed polarities, consistent with a pre-Kiaman (Permo-Carboniferous) age for the magnetization, and (4) the paleopole position does not

TABLE 1. Characteristic (A) Magnetizations of Terrenceville Formation

\begin{tabular}{|c|c|c|c|c|c|c|c|c|}
\hline \multirow[b]{2}{*}{ Site } & \multirow[b]{2}{*}{$R_{s}$} & \multirow[b]{2}{*}{$P_{s}$} & \multicolumn{2}{|c|}{ In Situ } & \multirow[b]{2}{*}{$k$} & \multirow[b]{2}{*}{$a_{95}$} & \multicolumn{2}{|c|}{ Tilt Corrected } \\
\hline & & & Declination & Inclination & & & Declination & Inclination \\
\hline A & $4 / 7$ & $2 / 2$ & $182.8^{\circ}$ & $29.6^{\circ}$ & 8 & $35.3^{\circ}$ & $187.9^{\circ}$ & $24.7^{\circ}$ \\
\hline B & $4 / 5$ & $1 / 3$ & 184.6 & 38.3 & 40 & 14.7 & 170.6 & 35.9 \\
\hline C & $4 / 6$ & $1 / 3$ & 171.8 & 21.8 & 16 & 23.4 & 181.3 & 30.6 \\
\hline D & $5 / 7$ & $0 / 5$ & 166.8 & 40.5 & 57 & 10.2 & 171.5 & 30.5 \\
\hline $\mathbf{E}$ & $4 / 5$ & $4 / 0$ & 8.4 & -24.6 & 54 & 12.7 & 8.4 & -24.6 \\
\hline $\mathrm{F}$ & $7 / 7$ & $0 / 7$ & 188.7 & 22.6 & 60 & 7.8 & 193.0 & 1.2 \\
\hline $\mathbf{G}$ & $4 / 5$ & $0 / 4$ & 147.8 & 25.6 & 28 & 17.6 & 159.6 & 35.1 \\
\hline $\mathbf{H}$ & $6 / 6$ & $6 / 0$ & 345.4 & -6.9 & 15 & 17.9 & 355.6 & -30.5 \\
\hline I & $4 / 6$ & $0 / 4$ & 185.4 & 20.2 & 9 & 33.2 & 203.1 & 33.5 \\
\hline $\mathbf{J}$ & $0 / 6$ & - & - & - & - & - & - & - \\
\hline
\end{tabular}

In situ mean: $N=9$ sites, $D=175.8^{\circ}, I=26.2^{\circ}$ (42/60 samples), $k=26, a_{95}=10.3, R=8.692$; tiltcorrected mean: $D=181.6^{\circ}, I=28.0^{\circ}, k=27, a_{95}=10.1, R=8.704$. In situ pole position: latitude = $28.4^{\circ} \mathrm{N}$, longitude $=129.9^{\circ} \mathrm{E}, d p, d m=6.0^{\circ}, 11.2^{\circ}$; tilt-corrected pole position: latitude $=27.4^{\circ} \mathrm{N}$, longitude $=123.6^{\circ} \mathrm{E}, d p, d m=6.1^{\circ}, 11.1^{\circ} . R_{s}$ is the ratio of samples in which A component identified to the number of samples collected; $\boldsymbol{P}_{s}$ is the number of samples with normal polarity to number with reversed polarity; $k$ and $a_{95}$ are the best estimate of Fisher's precision parameter and the semi-axis of the circle of $95 \%$ confidence, respectively; $R$ is the resultant length of $N$ unit vectors; $d p, d m$ are the semi-axes of the oval of $95 \%$ confidence. 
TABLE 2. Thermally Distributed B Component Magnetizations of Terrenceville Formation

\begin{tabular}{|c|c|c|c|c|c|c|c|}
\hline \multirow[b]{2}{*}{ Site } & \multirow[b]{2}{*}{$\boldsymbol{R}_{\boldsymbol{s}}$} & \multicolumn{2}{|c|}{ In Situ } & \multirow[b]{2}{*}{$k$} & \multirow[b]{2}{*}{$a_{95}$} & \multicolumn{2}{|c|}{ Tilt Corrected } \\
\hline & & Declination & Inclination & & & Declination & Inclination \\
\hline A & $2 / 7$ & 183.9 & 1.7 & & & 183.8 & -2.9 \\
\hline B & $4 / 5$ & 187.8 & -3.9 & 94 & 9.5 & 188.9 & -2.8 \\
\hline C & $6 / 6$ & 191.0 & -5.4 & 53 & 8.4 & 189.7 & -1.5 \\
\hline D & $4 / 7$ & 182.4 & 0.4 & 204 & 6.5 & 182.0 & -10.9 \\
\hline $\mathrm{E}$ & $0 / 5$ & - & - & - & - & - & - \\
\hline $\mathbf{F}$ & $6 / 7$ & 179.6 & 0.9 & 73 & 7.9 & 176.4 & -15.6 \\
\hline G & $0 / 5$ & - & - & - & - & - & - \\
\hline $\mathbf{H}$ & $1 / 6$ & 197.8 & -18.7 & & & 188.9 & -8.4 \\
\hline I & $2 / 6$ & 173.1 & -4.0 & & & 177.0 & 19.6 \\
\hline $\mathbf{J}$ & $4 / 6$ & 192.2 & 2.9 & 53 & 12.7 & 191.9 & -23.0 \\
\hline
\end{tabular}

In situ mean: $N=8$ sites, $D=185.9^{\circ}, I=3.3^{\circ}$ (29/60 samples), $k=61, a_{95}=7.2^{\circ}$; tilt-corrected mean: $D=184.9^{\circ}, I=-5.8^{\circ}, k=35, a_{95}=9.6^{\circ}$. In situ pole position: latitude $=43.6^{\circ} \mathrm{N}$, longitude $=$ $117.1^{\circ} \mathrm{E}, d p, d m=3.6^{\circ}, 7.2^{\circ} ;$ tilt corrected pole position: latitude $=45.0^{\circ} \mathrm{N}$, longitude $=118.4^{\circ} \mathrm{E}, d p$, $d m=4.8^{\circ}, 9.6^{\circ} . R_{s}$ is the ratio of samples in which B component identified to the number of samples collected; other parameters same as for Table 1.

fall near any known segment of the apparent polar wander paths for either North America or Acadia since the Carboniferous, the likely age of deformation of the Terrenceville Formation. The A component magnetizations are therefore considered a record of the paleomagnetic field near to the time of deposition of the Terrenceville Formation in the Late Devonian.

Irving and Opdyke [1965] suggested that blocking temperature spectra of red bed magnetizations may be grain size dependent. They associated thermally discrete components with larger specular grains of hematite and thermally distributed components with finely divided, pigmentary hematite. A similar association may account for the presence of two components of magnetization, both apparently carried by hematite, in the Terrenceville wherein physically separate phases of hematite either formed or acquired their magnetization at different times. In this case, the phase with a discrete blocking temperature (A component) is hypothesized to have formed early in the history of the rock unit and may possibly carry a detrital remanence, while the secondary, thermally distributed B component developed by subsequent formation of pigmentary hematite. Remagnetization of preexisting hematite during burial and uplift after folding is an alternative explanation for acquisition of the B component.

Some chemical demagnetization experiments were conducted to test this hypothesis, with the expectation that the B component would be removed initially if carried by finegrained (more soluble?) hematite and the A component over longer leaching times if carried by larger (less soluble?) specular grains of hematite. Despite erratic directional behavior in the initial stages of acid leaching, during which the samples lost most of their red coloration, a more consistent pattern of decay to the origin at longer leaching intervals provides evidence for the removal of a final component of magnetization (Figure 5). This last component, which persists over more than 1000 hours of acid treatment, is similar in direction to the thermally discrete A component. The available chemical demagnetizations are thus not inconsistent with a coarse-grained hematite carrier for the characteristic magnetizations. The poor chemical resolution of the $B$ component may be due to rapid and nonhomogeneous leaching of the red pigment complicated by the presence of more recent magnetizations.

\section{Discussion AND Tectonic IMPlications}

The A paleopole, derived from the characteristic directions of both normal and reversed polarity which are thought to represent the paleomagnetic field near the time of deposition of the Terrenceville Formation in the Late Devonian, falls within the group of poles obtained from coeval stratified rock units that are part of the Acadia displaced terrain (Figure 6). This correspondence indicates that the Avalon Platform, on which the Terrenceville Formation lies, can be considered part of Acadia and that these areas were together situated some $15^{\circ}$ of latitude south of their present position on the basis of comparison with Middle to Late Devonian paleopoles from cratonic North America. Although Carboniferous or Permian paleomagnetic data are not available from the Avalon Platform, it seems probable that this area shared the same history of displacement as documented for Acadia, by left-lateral translation during the Carboniferous. The correspondence of the B paleopole, which presumably originated after folding, with Early to Late Permian pole positions for North America (Figure 6) is consistent with this view and also suggests that the gentle folding of the Terrenceville Formation occurred in the Carboniferous (between deposition in the Late Devonian and the acquisition of the secondary B component by the Permian). This is the interval

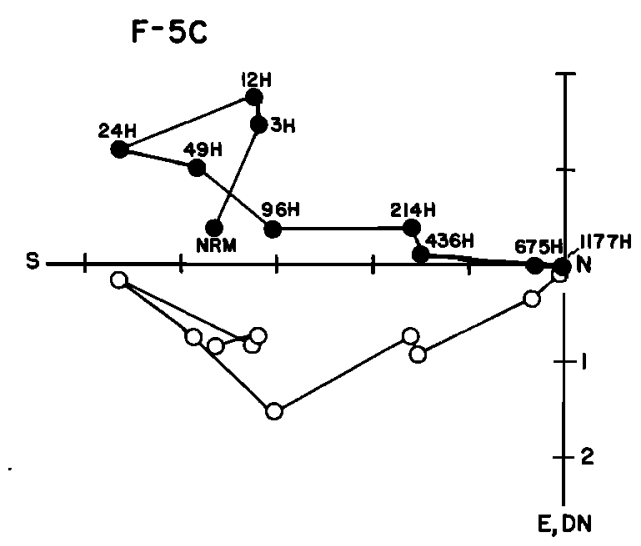

Fig. 5 Orthogonal projection of vector end point diagram of chemical demagnetization of Terrenceville sample. Sample was slotted and kept in field-free space while immersed in $8 \mathrm{~N} \mathrm{HCl}$ for indicated cumulative time intervals. Explanations of symbols and axes units same as Figure 2. 


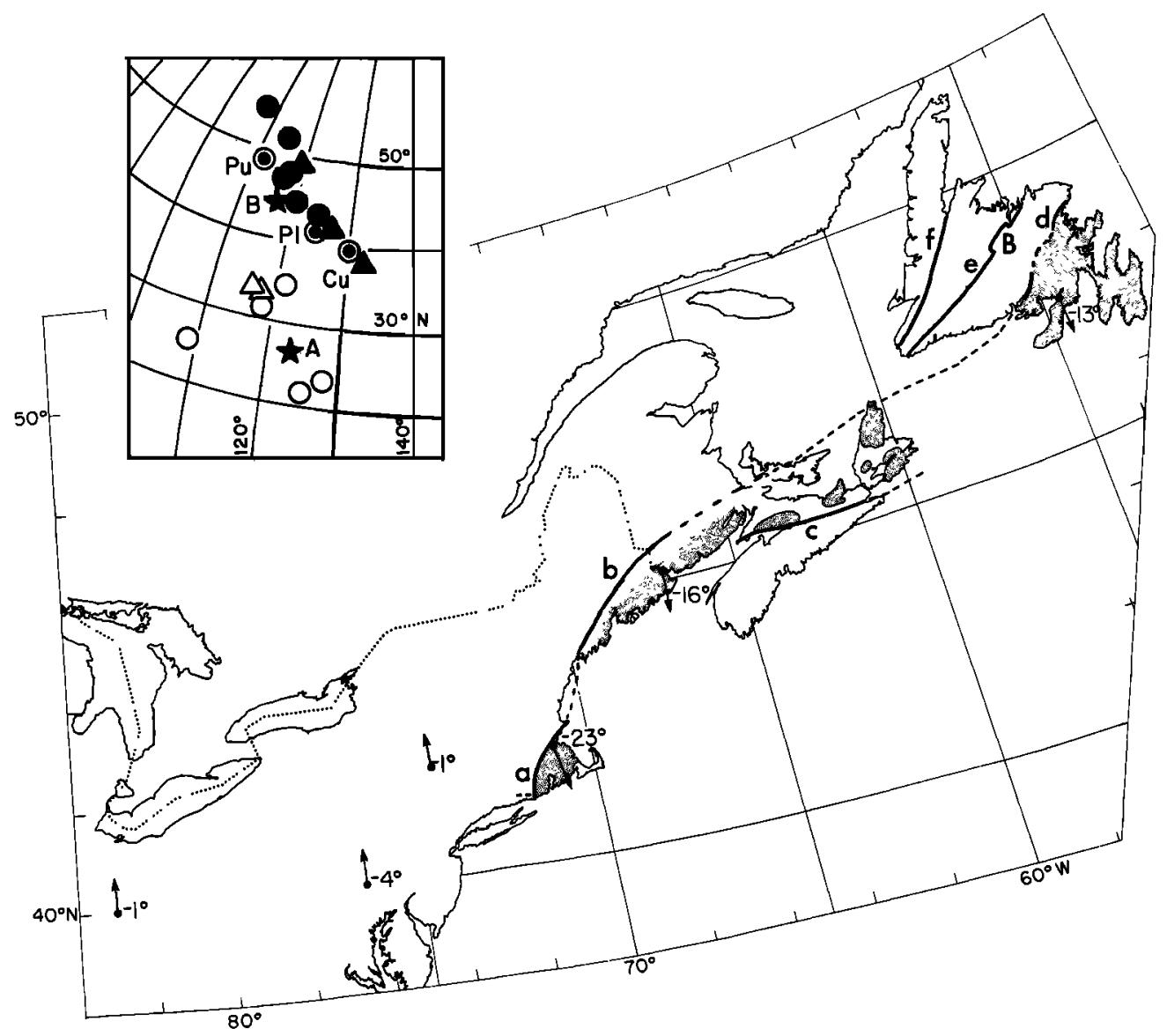

Fig. 6. Paleomagnetic data available from Middle to Upper Devonian rock units in northeastern North America. Points indicate sampling localities, extending arrows the paleomeridian, and adjacent numbers the inferred paleolatitude. Shaded area represents Avalonian outcrop belt, which generally coincides with areas of more southerly paleolatitudes in Devonian, evidence for the Acadia displaced terrain. Possible bounding fault zones for Avalonian terrain are labeled a, Lake Char and Clinton-Newbury; b, Norumbega and Fredericton; c, Cobequid and Chedabucto; d, Dover and Hermitage; e, Cape Ray and Reach; f, Cabot. Location of Botwood area noted as B. Inset shows late Paleozoic paleopoles from North America plotted in present coordinates (see Van der Voo and Scotese [1981] for compilation). Open circles and triangles represent poles of corresponding ages from cratonic North America. Mean late Carboniferous (Cu), Early Permian (Pl) and Late Permian (Pu) for North America [from Van der Voo and French, 1974]. Stars show locations of characteristic A and secondary B paleopoles obtained from Upper Devonian Terrenceville formation of Newfoundland.

associated with Alleghenian deformation elsewhere in the Appalachians [e.g., Van der Voo, 1979]. Even if the A component is also considered a secondary magnetization significantly postdating deposition of the Terrenceville Formation, a relative northward displacement of the Avalon Platform is nevertheless still indicated (although at a correspondingly later time) because the A paleopole cannot easily be reconciled otherwise with reliable post-Devonian poles from North America.

The association between Devonian rock units yielding paleopoles indicative of displacement and geological terrains with Avalonian affinities can now be extended to the type area of the Avalonian belt on the Avalon Platform (Figure 6). Thus Acadia, a late Paleozoic displaced terrain on the basis of paleomagnetic data [Kent and Opdyke, 1979] appears to correspond closely to the northern Avalonian belt, defined largely on the basis of late Precambrian-early Paleozoic lithotectonic development. Major fault zones seem to lie near the margins of the Avalonian belt in the northern Appalachians, for example, the Lake Char and ClintonNewbury faults in southern New England, the Norumbega and Fredericton faults in northern New England and New
Brunswick, the Cobequid and Chedabucto faults in Nova Scotia, and the Dover and Hermitage faults in Newfoundland. Some of these faults may be the locus of Carboniferous transcurrent motion required to bring the northern Avalonian belt to its present position. Earlier suggestions that late Paleozoic displacements involved areas as far north as central Maine [Brown, 1979], north of the Norumbega Fault and the recognized Avalonian belt have not been supported by later work [Brown and Kelly, 1980]. Anomalous paleopoles from Lower Devonian rocks in central New England and southern Quebec are better explained as the result of pre-Carboniferous tectonic rotation of a separate (Traveler) block lying inboard the Avalonian belt [Spariosu and Kent, 1982].

In Newfoundland the inboard extent of a terrain displaced in the late Paleozoic, as documented here for the Avalon Platform, is, however, still not well constrained. While lithotectonic characteristics and paleomagnetic data [Deutsch and Rao, 1977] indicate that western Newfoundland can be considered part of cratonic North America, there are few paleomagnetic data to help establish affinities of central Newfoundland with either cratonic North America or 
the Avalonian belt. One set of results, from Silurian stratified rock units of the Botwood area [LaPointe, 1979], gives similar pole positions to those derived from Siluro-Devonian rocks from the coastal volcanic belt of Maine [Kent and Opdyke, 1980]. This similarity suggests that the Botwood area of central Newfoundland might be included with the Avalonian belt in late Paleozoic displacements. Major faults to the west of the Botwood area, for example, the Cape RayReach fault [McKerrow and Cocks, 1977] or the Cabot fault (Figure 6), rather than faults to the east (e.g., Dover and/or Hermitage) would then be candidates for large-scale sinistral transcurrent motion in the Carboniferous.

Until the affinities of areas lying between the Avalonian belt and cratonic North America are better established, reference to the Avalonian belt as the terrain also displaced in the late Paleozoic should be used advisedly. Areas of the northern Appalachians besides the Avalonian belt may have been involved, such as in central Newfoundland, while the involvement in large latitudinal displacements of Avalonian belt rocks in the southern Appalachians has not yet been demonstrated. The extent of latitudinally displaced terrains in the Appalachians is likely to be governed by the position of late transcurrent faults which may not always coincide with the boundaries between regions of contrasting earlier lithotectonic development.

In a megatectonic sense, the Terrenceville paleomagnetic results fit nicely into the emerging picture of Middle to Late Devonian paleogeography of the Atlantic-bordering continents (Figure 7). The Avalonian belt extending southward from Newfoundland to New England appears as a promontory of a larger landmass composed of Armorica, including Britain south of the Great Glen Fault [Van der Voo and Scotese, 1981] and Baltica. The North American craton or Laurentia lay to the west but was offset by some $1500 \mathrm{~km}$ to the north compared to conventional late Paleozoic recon-

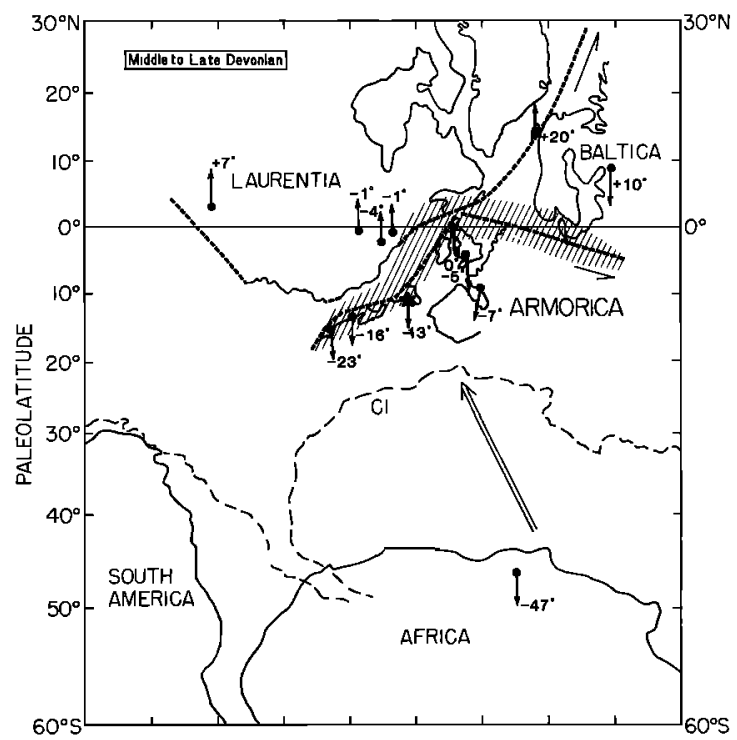

Fig. 7. Paleogeographic map for Middle to Late Devonian time [after Van der Voo and Scotese, 1981]. Paleomagnetic results have been used to position continental blocks and are shown as arrows (declinations) with their paleolatitude values. Results from Terrenceville A component magnetization indicated by star symbol. Position of Africa-South America in early Carboniferous (dashed outline, labeled $\mathrm{Cl}$ ) based on paleopole from Dwyka varves [McElhinny and Opdyke, 1968]. structions of Euramerica [Bullard et al., 1965]. Although longitudinal control is lacking, the absence of evidence for major intervening ocean basins in the late Paleozoic favors a predominantly strike slip (sinistral) motion to resolve the offset between eastern and western Euramerica. This largescale faulting within Euramerica, which most probably occurred in the Carboniferous, is likely to be related to the progressive impingement of the Gondwana continent [LeFort and Van der Voo, 1981]. An objective of further research is to reconcile geological and paleomagnetic evidence for the location and history of the fault zones which accommodated these hypothesized large-scale movements.

Acknowledgments. I thank J. E. T. Channell and R. A. Schweickert for critical reviews of the manuscript; D. J. Spariosu, S. Conklin, and C. A. Kent for field assistance; and Doris Lafferty for superb laboratory work. Research was supported by the National Science Foundation, Earth Sciences, under grant EAR80-07748. Lamont-Doherty Geological Observatory Contribution 3373

\section{REFERENCES}

Bradley, D. A., Gisborne Lake and Terrenceville map area, Newfoundland, Mem. 321, 56 pp., Can. Geol. Surv., Ottawa, 1962.

Brown, L., Paleomagnetic results from northern Maine and the western limit of 'Avalon' in the mid-Paleozoic, Geophys. Res. Lett., 6, 821-824, 1979.

Brown, L., and W. M. Kelly, Paleomagnetic results from northern Maine-Reinterpretations, Geophys. Res. Lett., 7, 1109-1111, 1980.

Bullard, E. C., J. E. Everett, and A. G. Smith, A symposium on continental drift, IV, The fit of the continents around the Atlantic, Philos. Trans. R. Soc. London, Ser. A, 258, 41-51, 1965.

Deutsch, E. R., and K. V. Rao, New paleomagnetic evidence fails to support rotation of western Newfoundland, Nature, 266, 314318, 1977.

Ellwood, B. B., Paleomagnetic evidence for the continuity and independent movement of a distinct major crustal block in the southern Appalachians, J. Geophys. Res., 87, 5339-5350, 1982.

Fisher, R. A., Dispersion on a sphere, Proc. R. Soc. London, Ser. $A, 217,295-305,1953$.

Goree, W. S., and M. Fuller, Magnetometers using RF-driven squids and their applications in rock magnetism and paleomagnetism, Rev. Geophys. Space Phys., 14, 591-608, 1976.

Irving, E., Paleopoles and paleolatitudes of North America and speculations about displaced terrains, Can. J. Earth Sci., 16, 669694, 1979.

Irving, E., and N. D. Opdyke, The paleomagnetism of the Bloomsburg red beds and its possible application to the tectonic histoy of the Appalachians, Geophys. J. R. Astron. Soc., 9, 153-166, 1965.

Irving, E., and G. Pullaiah, Reversals of the geomagnetic field, magnetostratigraphy, and relative magnitude of paleosecular variation in the Phanerozoic, Earth Sci. Rev., 12, 35-64, 1976.

Kent, D. V., and N. D. Opdyke, Paleomagnetism of the Devonian Catskill red beds: Evidence for motion of coastal New EnglandCanadian Maritime region relative to cratonic North America, $J$. Geophys. Res., 83, 4441-4450, 1978.

Kent, D. V., and N. D. Opdyke, The early Carboniferous paleomagnetic field of North America and its bearing on tectonics of the northern Appalachians, Earth Planet. Sci. Lett., 44, 365-372, 1979.

Kent, D. V., and N. D. Opdyke, Paleomagnetism of Siluro-Devonian rocks from eastern Maine, Can. J. Earth Sci., 17, 1653-1665, 1980.

King, P. B., The Evolution of North America, 197 pp., Princeton University Press, Princeton, N. J., 1977.

LaPointe, P. L., Paleomagnetism and orogenic history of the Botwood Group and Mount Peyton Batholith, Central Mobile Belt, Newfoundland, Can. J. Earth Sci., 16, 866-876, 1979.

LeFort, J., and R. Van der Voo, A kinematic model for the collision and complete suturing between Gondwanaland and Laurussia in the Carboniferous, J. Geol., 89, 537-550, 1981.

McElhinny, M. W., Statistical significance of the fold test in paleomagnetism, Geophys. J. R. Astron. Soc., 8, 338-340, 1964. 
McElhinny, M. W., and N. D. Opdyke, Paleomagnetism of some Carboniferous glacial varves from Central Africa, J. Geophys. Res., 73, 689-696, 1968.

McKerrow, W. S., and L. R. M. Cocks, The location of the Iapetus suture in Newfoundland, Can. J. Earth Sci., 14, 488-495, 1977.

Molyneux, L., A complete result magnetometer for measuring the remanent magnetization of rocks, Geophys. J. R. Astron. Soc., $10,429,1971$.

Schenk, P. E., Synthesis of the Canadian Appalachians, Pap. 78-13, 111-136, Can. Geol. Surv., Ottawa, 1978.

Spariosu, D. J., and D. V. Kent, Paleomagnetism of the Lower Devonian Traveler Felsite and the Acadian orogeny in the New England Appalachians, Geol. Soc. Am. Bull., in press, 1982.

Van der Voo, R., Age of the Alleghenian folding in the central Appalachians, Geology, 7, 297-298, 1979.

Van der Voo, R., and R. B. French, Apparent polar wandering for the Atlantic-bordering continents: Late Carboniferous to Eocene, Earth Sci. Rev., 10, 99-119, 1974.

Van der Voo, R., and C. Scotese, Paleomagnetic evidence for a large $(\sim 2000 \mathrm{~km})$ sinistral offset along the Great Glen fault during Carboniferous time, Geology, 9, 583-589, 1981.
Van der Voo, R., A. N. French, and R. B. French, A paleomagnetic pole position from the folded Upper Devonian Catskill redbeds, and its tectonic implications, Geology, 7, 345-348, 1979.

Williams, H., Pre-Carboniferous development of Newfoundland Appalachians, North Atlantic Geology and Continental Drift, edited by M. Kay, Mem. Am. Assoc. Petrol. Geol., 12, 32-58, 1969.

Williams, H., Tectonic lithofacies map of the Appalachian orogen, Map 1, Memorial Univ., St. John's, Newfoundland, 1978.

Williams, H., Appalachian orogen in Canada, Can. J. Earth Sci., 16, 792-807, 1979.

Zijderveld, J. D. A., A.C. demagnetization of rocks: Analysis of results, in Methods in Paleomagnetism, edited by D. W. Collinson, K. M. Creer, and S. K. Runcorn, pp. 254-286, Elsevier, New York, 1967.
(Received April 13, 1982; revised July 26, 1982; accepted July 29, 1982.) 